\title{
Wastages of the grocery in retailing in Uttarakhand
}

\author{
Effulgence \\ Vol. 16 (Special Issue) \\ January - June, 2018 \\ Rukmini Devi Institute of Advanced Studies \\ E-mail : effulgence@rdias.ac.in, Website :www.rdias.ac.in \\ http://effulgence.rdias.ac.in/user/default.aspx \\ https://dx.doi.org/10.33601/effulgence.rdias/v16/iSpl1/2018/article0.15
}

\begin{abstract}
Rishi Raj, Research Scholar, Hemwati Nanadan Bahuguna University Srinager, UK, rishirajrajan@hotmail.com

Dr. G C Dangwal, Assistant Professor, Government Degree College, Raipura, Dehradun, UK, gcdangwal.dangwal@gmail.com
\end{abstract}

\begin{abstract}
Wastages is the compulsory activity of the production and business activity and most of the time it is accepted by the organization as its necessary outcome. But efficiency within the organization, resource based view, value chain aspect, profit making stages draw the attention towards the wastages. Various industry wastages are recyclable or reusable for further use or for profit generation, but food and grocery business are such a business activity in which no concept of reuse persist. Since food is natural product and is basic and primary need of human, perishing in nature, no recycling is possible here and may develop many social and economic problems if not taken seriously, so needs special attention by the policy makers.

Growing volume of waste, generated in both production and consumption of goods and services, unbalanced growth in population worldwide, increase in life expectancy age of population, reducing mortality rate due to medical advances has resulted in a larger pool of waste generator. Rise in per capita income of new developing areas like China, India, South East Asian nations, has to increase demand for goods and services led to rise in wastages of food and their products

In this study, (a part of $\mathrm{Ph}$. D.) through direct findings of percentage of wastages of grocery retailers and comparison between the two major cities of Garhwal region Haridwar and Dehradun has been done. It is a primary effort to find out the wastages level of grocery retailing business in this hilly region.
\end{abstract}

Key words: efficiency, resource based view, value chain 


\section{INTRODUCTION}

World producer have enough food to fed every one of us, yet almost $1 / 7^{\text {th }}$ of the world population i.e.1 billion population live in hunger.

Between $1 / 3$ and $1 / 2$ of all food produced is wasted or lost along supply chain every year.

In developed countries, consumers are responsible for most of the food waste (38-48\%).

The proportion of food thrown away by the retailers is the lowest, at around $5 \%$ still.

Food retailers have knowledge and means to influence how consumer buy cook and even store and dispose food at home.

The Indian retail sector is highly fragmented and mostly consists of owner-run mom and pop stores. The whole sector is dominated by small retailers consisting of local Kirana shops, General Stores, Apparel and Footwear Shops, Hand Cart Hawkers and Pavement Vendors. As per Investment Commission of India estimates, there are over 15 million mom and pop retail outlets in the country. Infact, 95 percent of the small retailers occupy less than $500 \mathrm{sq}$ feet of space. The Indian retail market is dominated by the kirana stores and this unorganized retail trade has created nearly 40 million (almost 9.2 percent of country's population) employment opportunities in the nation'. Report by Ernst \& Young's on 'The Great Indian Retail Story', anticipates the Indian retail sector to add up 2 million employment opportunities within the year 2010. More than 80 percent of these retail outlets are managed and run by individual and family members." With India's economic growth, the retail sector is not only expanding but also modernizing. This new trend began during late 1990s and early 2000s. In the midst of the unorganized retail sector's strong dominance, some of the major industrial houses have entered into this sector and have announced ambitious future expansion plans. Transnational corporations have also joined hands with big Indian companies to set up retail chains. The demand side characteristics such as moderately high economic growth, ever expanding middle and upper class consumer base, high urbanization rate, increasing share of women in workforce and greater availability of personal credit were definitely favorable for a greater penetration of modern retail in the economy.

Wastages are inbuilt tendency of the process at it's various stages, production, storage, transportation, retailing, consumption etc.. In most of the cases due to our nature of negligence or somehow selling the stock, or reducing the loss or unawareness about product is responsible for Substandard delivery by the retailers. Reducing food losses and waste should be approached from a system perspective to ensure that isolated actions do not shift losses and waste to other stages of supply chain.

Grocery items generally starts to get rots in forms or fields, in transit, at warehouses, at the time of threshing, cutting, carrying, loading unloading, at the time of packing, at the time of retailing at shop and at the time of weighing and packing at retailers shop. The nature of product also matters a lots to get waste during the various stages, and is unavoidable, and can be reduced only by adopting certain precautionary measures. "Food waste may be more finely classified as food loss when incurred during early phases of the food supply-chain, and as food waste within latter phases. Food loss occurs in production, storage, transport, and processing, which are the stages of the value chain with the lowest returns. Conversely, food waste generated at the end of the supply-chain within retail and final consumption is synonymous with higher value-chain potential; but also represents higher costs when diverted away from human consumption"-(A Global Food Security Report Of UK) Grocery wastage is a problem along the entire food supply chain and gives rise to great financial losses and waste of natural resources. The retail stage of the supply chain contributes significant masses of waste. In order to introduce efficient waste reduction measures, the wastage problem must first be properly described. Causes of wastage need to be identified before potential measures can be designed, tested and evaluated. (Erikson2012) We must understand the stages of wastages in grocery retailing. Production losses was very less nearly $2 \%$ in case of groceries, post harvest and storage losses was very high due to lack of infrastructure as warehouses, cold storage, and lack of proper use of technology, 
next was processing and packing wastage which was highest in case of grocery product, next stage wastage was transportation and loading and unloading. In the United States (US) today up to $50 \%$ of food produced for consumption was wasted in some stage of production, distribution, or preparation. Foreign studies also indicated that retail food wastage for different product groups was often between 0 and $10 \%$, which was similar to the range reported in Swedish studies. Many previous studies had focused on fruit and vegetables, which often gave high percentage waste, e.g. $10 \%$ for the European retail distribution sector according to Gustavsson et al. (2011). Fehr et al. (2002) reported $8.76 \%$ retail waste in Brazilian supermarkets. This wastage could be made less by adopting appropriate packing format, using skilled staff, next was the stage of retailing where possibility of wastages and substandard delivery was highest, (in our study wastages were up to $17.2 \%$ ) as getting suggestion and views from retailers, we found that technical up gradation as improved storage system, weighing system and modern packing format, skilled and trained staff, appropriate inventory, avoiding tendency of over stock and selling the old stock at any cost were few measures which had to be adopted by the retailers to reduce the substandard delivery wastages. Grocery waste was more apparent, and easier to define, towards the end of the supply chain. At the producer level, though, the issue was much more complex, particularly in relation to onfarm losses. In our view food grown but not harvested due to adverse weather conditions should not be considered as grocery waste. On the other hand, food not harvested for other reasons, such as change in demand, should be included within the definition of grocery waste. After observing the difficulties of defining grocery waste; we turned to its monitoring. The lack of data was related to the difficulty of monitoring losses at this stage of the food supply chain as well as the definitional problem of classifying what is grocery waste $\bullet$ in the field. It was clear from the evidence that individual hospitality and food sector and retail businesses, by contrast, are in a relatively good position to assess their own grocery waste when motivated to do so. We find that grocery waste is a poor area as for as data collection is concerned across the main sectors where it arises. In some instances it is possible, particularly among large retailers. It is, however, much more difficult to assess the quantity and nature of grocery waste at the producer, manufacturer and consumer levels and within smaller businesses in particular. Growing volume of waste generated in both production and consumption of goods and services. Unbalanced growth of population worldwide and increase in life expectancy age of person and reduced mortality rates due to medical advances. This has resulted in a larger pool of waste generator.

\section{Significance of Study}

Problem of the study emanates with the convention that organized sector is growing very fast and covering almost whole of the retail market rapidly in India. Further organized sector always proceeds in the market with heavy investments and large turnover having the shelter of government while the unorganized retails do not have such a strategy or facility to protect their interest, even their survival too. Organized sector cover whole of the market with great impetus of various market tools such as advertisement, discounts etc. while the unorganized retail do not adopt such methods to influence the market. Unorganized sector even do not have proper association to protect their interest and now a question of its survival has aroused.

Generally each market has certain structure and level and its trend and so should be in this case. This is very necessary to understand these factors for deciding the future growth of the unorganized retailing of the state. We observed the issue from consumption of grocery point of view so certainly there would be some concept flaws which might be opposite to some prior conception about the market, as in case of Mandi Samiti, what we think is mainly a place of wholesalers and traders only. But it is not true, retailers' play an important role in their day to day business at mandi and not only this, few retailer itself work as a whole seller there. This step helps to eliminate the replication of work and provide useful basis for the formulation of hypothesis.There is a dire need of research from various points of view regarding the retailing in 
Uttarakhand. Unorganized retailing is so scattered and powerless due to lack of, as is clear by its name "Unorganized" that any one least understand its need of existence. Though everyone know its power of easy reach, power of providing employment, consumer relationship, service, market hold, product placement, product development, yet least interested for framing any logic for its development. Effort of explaining the Significance of the study is being done by raising the some research question regarding the development of frame work of the study.

\section{RESEARCH QUESTION}

What is the volume of wastages in unorganized retailing in Uttarakhand and how it can be stopped.

What are the wastage related issues of the grocery retailing which reduces the profitability of grocery retailing and make it less attractive to initiate?

\section{RESEARCH GAP}

Even though a lot of work has been done over the various aspects in retailing for Uttarakhand but grocery retailing from unorganized retailing facet and its role in food wastages was untouched and little understood. Grocery is an important item from house hold point of view and is a promising area to grow due to regular need of consumer and good margin of profit. In the light of present market scenario very little work has been done over this issue in Uttarakhand which has its own need and necessity.

\section{OBJECTIVES}

The main objectives of the present study is

1. To find out the causes and volume of substandard delivery of groceries and wastages and suggest measures for improvement.

\section{HYPOTHESES}

According to Landburg "A hypothesis' is a tentative generalization, the validity of which remains to be tested, in its most elementary stages, the hypothesis may be a guess, elementary idea or situation, whatsoever which becomes the basis for investigation or action". To cover the main objectives for which topic was planned and thought to be carried out under the set assumptions (Hypotheses). These hypotheses are working hypotheses in nature. Working hypothesis is tentative assumption made in order to draw out and test its logical or empirical consequences.

$\mathrm{H1}$ : Grocery retailing has sufficient amount of wastages which makes it less attractive.

\section{RESEARCH METHODOLOGY}

Research methodology focuses the whole process of conducting empirical research study. I used a multi-stage stratified approach. Before applying the approach, one needed a basic theory from which such estimates were created. The frame work used in this study was as follows:-

1. Method of study

2. Sampling Design
a. Selection of Area (Region)
b. Selection of Districts
c. Selection of Mandies
d. Selection of Grocery Retailers
e. Selection of Grocery Customers

3. Method of Investigation
a. Collection of Primary Data
b. Collection of Secondary Data

4. Method of Analysis of Data

\section{ANALYSIS OF FINDINGS}

\section{Wastages in Various Formats of Retailing}

Table-1: The mandi-wise wastages in various formats of retailing by sample grocery retailers during 2012-13 analyzed in Table-1 indicated that in the gunny bags format of retailing the wastages was estimated to $15.63 \%$ wherein the maximum i.e. $8.27 \%$ wastage was estimated in case of fine cereals, $2.37 \%$ in coarse cereals $2.53 \%$ in pulses and $2.50 \%$ in other groceries. Thus, the maximum wastage was reported in case of fine cereals in Uttarakhand. While in case of plastic bags format of retailing on an overall in the 
Uttarakhand $8.28 \%$ wastage was estimated wherein the maximum i.e. $3.13 \%$ wastage was estimated in case of fine cereals, $2.85 \%$ in other groceries, $1.40 \%$ in coarse cereals against the minimum i.e. $0.87 \%$ wastage in case of pulses. Thus, in plastic bags format of retailing too the maximum wastage was reported in case of fine cereals. On theother hand in cases of other formats of the grocery retailing in Uttarakhand on an overall $14.57 \%$ total wastage was estimated wherein the maximum i.e. $7.75 \%$ wastage was estimated in case of fine cereals, $3.87 \%$ wastage in the coarse cereals, $1.68 \%$ in pulses and the minimum i.e. $1.30 \%$ wastage in cases of others groceries in Uttarakhand. Thus, it is obviously clear that in all the formats of grocery retailing, the maximum wastage were reported in fine cereals in Uttarakhand as a whole. The mandi-wise analysis showed that in case of gunny bags the wastages in total groceries was estimated to $16.0 \%$ in Garhwal division against $15.25 \%$ in Kumoun division. Among the main mandies the wastages were comparatively being $17.2 \%$ in Haridwar Union mandi and $16.5 \%$ in Rudrapur mandi respectively against $15 \%$ in Dehradun and $14 \%$ in Haldwani mandi. Thus, the wastage in gunny bags format was higher in Haridwar Union mandi and Rudrapur mandi in comparisons of Dehradun and Haldwani mandies of Uttarakhand. In plastic bags format the wastages were the minimum being $8.75 \%$ in Garhwal division and $8.28 \%$ in Kumoun division of Uttarakhand. Among the main mandies it was higher in Dehradun mandi estimated to $9.1 \%$ against the lowest wastage to $7.2 \%$ in Rudrapur mandi. In case of other formats the wastages were considerably higher being estimated to about $14 \%$ in both Garhwal as well as Kumoun division of Uttarakhand. 
Table-1 Mandi Wise Wastages in Various Formats of Retailing by Sample Grocery Retailers

\begin{tabular}{|c|c|c|c|c|c|c|c|c|c|c|c|c|c|c|c|c|c|}
\hline \multirow{3}{*}{$\begin{array}{l}\text { S.N } \\
\text { o. }\end{array}$} & \multirow[b]{3}{*}{$\begin{array}{c}\text { Mandies/Grocery } \\
\text { Retailers }\end{array}$} & \multirow{3}{*}{$\begin{array}{c}\text { No. of } \\
\text { Sampl } \\
\text { e } \\
\text { Retail } \\
\text { ers }\end{array}$} & \multicolumn{15}{|c|}{ Wastages in Various Formats of Retailing (In Percentage \%) } \\
\hline & & & \multicolumn{5}{|c|}{ Gunny Bags } & \multicolumn{5}{|c|}{ Plastic Bags } & \multicolumn{5}{|c|}{ Other Formats } \\
\hline & & & $\begin{array}{c}\text { Fine } \\
\text { Cere } \\
\text { al }\end{array}$ & $\begin{array}{c}\text { Coar } \\
\text { se } \\
\text { Cere } \\
\text { al }\end{array}$ & $\begin{array}{l}\text { Pul } \\
\text { se }\end{array}$ & $\begin{array}{l}\text { Othe } \\
\text { rs }\end{array}$ & $\begin{array}{c}\text { Tot } \\
\text { al }\end{array}$ & $\begin{array}{c}\text { Fine } \\
\text { Cere } \\
\text { al }\end{array}$ & $\begin{array}{c}\text { Coar } \\
\text { se } \\
\text { Cere } \\
\text { al }\end{array}$ & $\begin{array}{l}\text { Pul } \\
\text { se }\end{array}$ & $\begin{array}{l}\text { Othe } \\
\text { rs }\end{array}$ & $\begin{array}{c}\text { Tot } \\
\text { al }\end{array}$ & $\begin{array}{c}\text { Fine } \\
\text { Cere } \\
\text { al }\end{array}$ & $\begin{array}{l}\text { Coar } \\
\text { se } \\
\text { Cere } \\
\text { al }\end{array}$ & $\begin{array}{l}\text { Pul } \\
\text { se }\end{array}$ & $\begin{array}{l}\text { Othe } \\
\text { rs }\end{array}$ & $\begin{array}{c}\text { Tot } \\
\text { al }\end{array}$ \\
\hline A & Garhwal Division & & & & & & & & & & & & & & & & \\
\hline 1 & Dehra Dun Mandi & 5 & 7.5 & 3 & 2 & 2.5 & 15 & 4 & 1.5 & 0.6 & 3 & 9.1 & 6 & 5 & 2 & 1.5 & 14.5 \\
\hline 2 & $\begin{array}{l}\text { Total Garhwal } \\
\text { Division }\end{array}$ & 10 & 8.05 & 2.7 & 2.8 & 2.5 & 16 & 3.5 & 1.33 & 0.7 & 3.2 & 8.75 & 7 & 4 & 1.75 & 1.35 & $\begin{array}{c}14.1 \\
3\end{array}$ \\
\hline B & Kumoun Division & & & & & & & & & & & & & & & & \\
\hline 1 & Rudra Pur Mandi & 5 & 10 & 2 & 2 & 2.5 & 16.5 & 2.5 & 1.5 & 1.2 & 2 & 7.2 & 8 & 4 & 2 & 1.21 & 15.2 \\
\hline
\end{tabular}

Source: Field survey 
Table-2: The mandi-wise general details of grocery retailers of Uttarakhand worked out in Table-2 shows that in Uttarakhand as a whole the starting years of the retail shops of grocery were reported in between 1915-2005, wherein, in Garhwal division the retail shops were reported to be started in between 1930-2001. While in Kumoun division they were told to be started in between1915-2005. Among the mandies, the grocery retail shops in Haridwar Union mandi were reported to be started in between 19302001 but in Dehradun mandi the grocery retail shops were started in the year 1980 to 2001 . While in Kumoun division, the grocery retail shops were started in 1915 to 2005 wherein in
Rudrapur mandi the shops were started in 1995 to 2003 and in Haldwani mandi these were started in 1915 to 2005. All the retailers in the selected mandies were regular in Uttarakhand. Majority of grocery retailers told that cereals, pulses and others groceries were generally deal in these mandies the main sources of grocery procurement were itinerant merchant and few others. Also majority of retailers had viewed that they get grocery on proper rates and only a few had told that grocery was costly. The main causes of sub-standard grocery in Uttarakhand were local variety, low as well as high rates and adulteration. 
Table-2 Mandi Wise General Details of Grocery Retailers

\begin{tabular}{|c|c|c|c|c|c|c|c|c|c|c|c|c|c|c|c|c|c|c|}
\hline \multirow[b]{2}{*}{ S.No } & \multirow[b]{2}{*}{ Mandies } & \multirow{2}{*}{$\begin{array}{l}\text { No. of } \\
\text { Samp } \\
\text { le } \\
\text { Retail } \\
\text { er }\end{array}$} & \multirow{2}{*}{$\begin{array}{l}\text { Startin } \\
\text { g Year } \\
\text { of } \\
\text { Retaili } \\
\text { ng } \\
\text { Shop }\end{array}$} & \multirow{2}{*}{$\begin{array}{c}\text { Type } \\
\text { of } \\
\text { Retaile } \\
\text { r } \\
\text { (Reg./ } \\
\text { Non } \\
\text { Reg.) }\end{array}$} & \multicolumn{3}{|c|}{$\begin{array}{l}\text { Grocery } \\
\text { Dealt }\end{array}$} & \multicolumn{3}{|c|}{$\begin{array}{c}\text { Sources of } \\
\text { Grocery } \\
\text { Procured From }\end{array}$} & \multicolumn{2}{|c|}{$\begin{array}{l}\text { Do You Get } \\
\text { Grocery At } \\
\text { Proper Rate }\end{array}$} & \multicolumn{3}{|c|}{ If No Reason } & \multicolumn{3}{|c|}{$\begin{array}{c}\text { Causes of } \\
\text { Substandard of } \\
\text { Groceries }\end{array}$} \\
\hline & & & & & שֶׁ & $\frac{\mathscr{\infty}}{\Xi}$ & 站 & 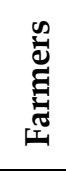 & 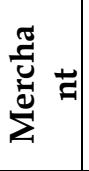 & 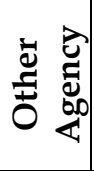 & $\stackrel{\infty}{\stackrel{D}{*}}$ & $\stackrel{\circ}{\mathbf{Z}}$ & $\frac{\lambda}{0}$ & 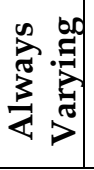 & 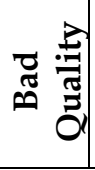 & 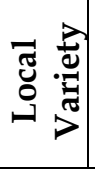 & 站 & 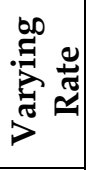 \\
\hline A & \multicolumn{18}{|c|}{ Garhwal Division } \\
\hline 1 & $\begin{array}{l}\text { Dehra Dun } \\
\text { Mandi }\end{array}$ & 5 & 1980-01 & regular & 5 & 5 & 4 & 0 & 3 & 2 & 4 & 1 & 1 & 0 & 0 & 1 & 2 & 2 \\
\hline 2 & $\begin{array}{c}\text { Haridwar } \\
\text { Union Mandi }\end{array}$ & 5 & $1930-90$ & regular & 4 & 3 & 2 & 0 & 4 & 1 & 3 & 2 & 0 & 1 & 1 & 0 & 2 & 3 \\
\hline & $\begin{array}{c}\text { Total Garhwal } \\
\text { Division }\end{array}$ & 10 & $\begin{array}{l}1930- \\
2001\end{array}$ & & 9 & 8 & 6 & 0 & 7 & 3 & 7 & 3 & 1 & 1 & 1 & 1 & 4 & 5 \\
\hline B & $\begin{array}{l}\text { Kumoun } \\
\text { Division }\end{array}$ & & & & & & & & & & & & & & & & & \\
\hline 1 & $\begin{array}{l}\text { Rudra Pur } \\
\text { Mandi }\end{array}$ & 5 & 1995-03 & regular & 4 & 3 & 4 & 0 & 5 & 0 & 5 & 0 & 0 & 0 & 0 & 0 & 1 & 4 \\
\hline 2 & $\begin{array}{l}\text { Haldwani } \\
\text { Mandi }\end{array}$ & 5 & 1915-05 & regular & 4 & 2 & 4 & 0 & 4 & 1 & 4 & 1 & 1 & 0 & 0 & 2 & 1 & 2 \\
\hline & $\begin{array}{c}\text { Total Kumoun } \\
\text { Division }\end{array}$ & 10 & 1915-05 & & 8 & 5 & 8 & 0 & 9 & 1 & 9 & 1 & 1 & 0 & 0 & 2 & 2 & 6 \\
\hline & $\begin{array}{c}\text { Total } \\
\text { Uttarakhand }\end{array}$ & 20 & 1915-05 & regular & 17 & 13 & $\begin{array}{l}1 \\
4\end{array}$ & 0 & 16 & 4 & 16 & 4 & 2 & 1 & 1 & 3 & 6 & 11 \\
\hline
\end{tabular}

urce: Field Surv 


\section{Causes and Solutions of Sub-Stand and Delivery}

Table-3:The Mandi-wise specific view of the sample grocery retailers of Uttarakhand worked out in Table-3 showed that majority of grocery retailers expressed their views that they use modern formats of grocery retailing and only a few viewed that modern formats were costly. Also majority of grocery retailers told to do unorganized retailing. The main cause of substandard delivery was adulteration by formers and village merchants and bad supply viewed by majority of retailers. The causes of wastage of groceries were lack of storage, poor transportation, small creatures like rat etc. and bad weather in Uttarakhand, absence of less similar. warehouses, as expressed by majority retailers. Few retailers were of the views that inventory management and procurement at retailer's level was another major reason of the wastages of the grocery product. Mishandling of the grocery at loading and unloading and at customers' delivery time was also assumed to be a major reason. Though it had been majorly removed by adopting the improved format in packing of grocery. The mandi-wise specific views of retailers indicated that in the main mandies of both Garhwal and Kumoun division the specific views expressed by the grocery retailers were more or 
Table-3 Mandi Wise Specific Views about grocery wastages of the Sample Grocery Retailers

\begin{tabular}{|c|c|c|c|c|c|c|c|c|c|}
\hline \multirow[b]{2}{*}{$\begin{array}{c}\text { S.N } \\
\text { o. }\end{array}$} & \multirow[b]{2}{*}{$\begin{array}{c}\text { Mandi/S } \\
\text { ample } \\
\text { Retailers }\end{array}$} & \multirow{2}{*}{$\begin{array}{c}\text { No. of } \\
\text { Sampl } \\
\text { es } \\
\text { Retail } \\
\text { ers }\end{array}$} & \multicolumn{7}{|c|}{ Causes of Wastages of Grocery } \\
\hline & & & $\begin{array}{l}\text { Lack Of } \\
\text { Storage }\end{array}$ & $\begin{array}{c}\text { Poor } \\
\text { Transp } \\
\text { ort }\end{array}$ & $\begin{array}{c}\text { Miss } \\
\text { Handli } \\
\text { ng }\end{array}$ & $\begin{array}{c}\text { poor } \\
\text { invent } \\
\text { orymn } \\
\text { gmnt }\end{array}$ & $\begin{array}{l}\text { small } \\
\text { creatur } \\
\text { es }\end{array}$ & $\begin{array}{c}\text { at } \\
\text { delive } \\
\text { ry } \\
\text { time }\end{array}$ & $\begin{array}{c}\text { lack of } \\
\text { warehouse } \\
\text { s }\end{array}$ \\
\hline
\end{tabular}

Source: Field survey

\begin{tabular}{|c|c|c|c|c|c|c|c|c|c|}
\hline A. & & & & & & & & & \\
\hline 1. & $\begin{array}{c}\text { Dehradu } \\
\text { n Div. }\end{array}$ & 5 & 3 & 3 & 1 & 3 & 4 & 3 & 2 \\
\hline \multirow[t]{2}{*}{2.} & $\begin{array}{c}\text { Haridwa } \\
\text { r Union }\end{array}$ & 5 & 5 & 4 & 2 & 5 & 5 & 4 & 1 \\
\hline & $\begin{array}{c}\text { Total } \\
\text { Garhwal } \\
\text { Div. }\end{array}$ & 10 & 8 & 7 & 3 & 8 & 9 & 7 & 3 \\
\hline
\end{tabular}

\begin{tabular}{|c|c|c|c|c|c|c|c|c|c|}
\hline B. & & & & & & & & & \\
\hline 1. & $\underset{r}{\text { Rudrapu }}$ & 5 & 5 & 3 & 2 & 5 & 5 & 5 & 3 \\
\hline \multirow[t]{3}{*}{2.} & $\begin{array}{c}\text { Haldwan } \\
\text { i Mandi }\end{array}$ & 5 & 2 & 3 & 2 & 2 & 3 & 4 & 1 \\
\hline & $\begin{array}{c}\text { Total } \\
\text { Kumoun } \\
\text { Division }\end{array}$ & 10 & 7 & 6 & 4 & 7 & 8 & 9 & 4 \\
\hline & $\begin{array}{c}\text { Total } \\
\text { Uttarakh } \\
\text { and }\end{array}$ & 20 & 20 & 13 & 7 & 15 & 17 & 16 & 7 \\
\hline
\end{tabular}


Graph-1.3

Mandi Wise Specific Facts about grocery wastages of the Sample Grocery Retailers

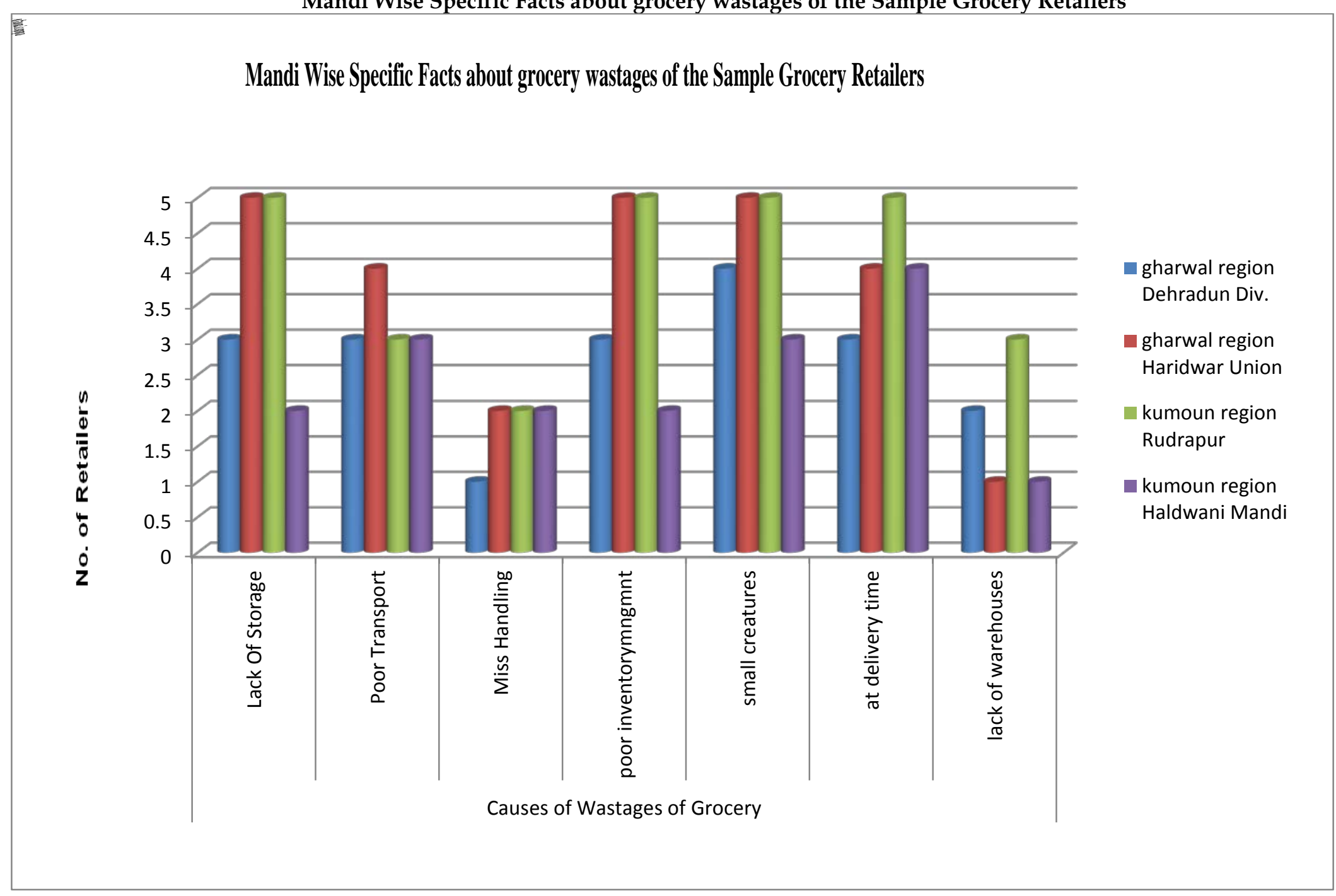


Table-4 The mandi-wise suggestions given by sample grocery retailers of Uttarakhand for improvement in grocery retailers worked out in Table- 4 indicated that on growth they had suggested to add more pulses item and its regular supply at proper rate and other availability of all groceries too. As regards the modern retailing almost all the sample retailers had suggested to increase the modern formats of grocery retailing. Also majority of retailers suggested reducing the sub-standard retailing. For wastes they suggested modern formats of retailing along with developed transportation as well as storage facilities in whole of Uttarakhand and its main mandies of groceries. The suggestion given by retailers are of varying nature related to problem of mandies, about structural growth of mandi, about development of new packing formats, reduce the substandard quality of grocery was a major concern of retailers, they were of the same view that by reducing the wastages, we could easily reduce the substandard delivery of groceries, the tendency to consume the wastages was one of the major reason of sub standard delivery. For reducing the losses occurred by wastages which was heavy in percentage, retailers generally tried to sell them out after drying, polishing, mixing, or reducing the price. This was the major cause of sub standard delivery. The tendency to mix external material was quite low and it didn't happen at retailers' level. Weather packing formats were other causes of substandard delivery. Lowering the product rates was another major reason of sub standard delivery. 
Table-4 Mandi Wise Suggestion Given by Sample Grocery Retailers for Improvement in Grocery Retailing

\begin{tabular}{|c|c|c|c|c|c|c|c|c|c|c|c|}
\hline \multirow[b]{2}{*}{ S.No. } & \multirow[b]{2}{*}{$\begin{array}{l}\text { No. of } \\
\text { Sample } \\
\text { Retailer }\end{array}$} & \multirow[b]{2}{*}{$\begin{array}{c}\text { Mandies/Grocery } \\
\text { Retailers }\end{array}$} & \multicolumn{3}{|c|}{ OnGrowth of Grocery Retailing } & \multicolumn{2}{|c|}{$\begin{array}{l}\text { Organized or } \\
\text { Unorganized }\end{array}$} & \multirow{3}{*}{$\begin{array}{c}\text { More } \\
\text { Modern } \\
\text { Retailing } \\
\text { To Be } \\
\text { Added }\end{array}$} & \multirow{3}{*}{$\begin{array}{c}\text { Sub } \\
\text { Standard } \\
\text { Retailing } \\
\text { To Be } \\
\text { Reduced }\end{array}$} & \multirow{3}{*}{$\begin{array}{l}\text { Wastage } \\
\text { Should } \\
\text { Be } \\
\text { Reduced }\end{array}$} & \multirow{3}{*}{$\begin{array}{c}\text { Transport } \\
\text { Should } \\
\text { Develop }\end{array}$} \\
\hline & & & \multirow[t]{2}{*}{$\begin{array}{l}\text { Additional } \\
\text { In Cereals }\end{array}$} & \multirow[t]{2}{*}{$\begin{array}{l}\text { Additional } \\
\text { In Pulse }\end{array}$} & \multirow[t]{2}{*}{$\begin{array}{l}\text { Additional } \\
\text { In Others } \\
\text { Grocery }\end{array}$} & \multirow[t]{2}{*}{$\begin{array}{c}\text { More } \\
\text { Organized }\end{array}$} & \multirow[t]{2}{*}{$\begin{array}{c}\text { More } \\
\text { Unorganized }\end{array}$} & & & & \\
\hline A & & Garhwal Division & & & & & & & & & \\
\hline 1 & 5 & Dehradun Mandi & 2 & 2 & 1 & 4 & 1 & 5 & 4 & 4 & 4 \\
\hline \multirow[t]{2}{*}{2} & 5 & Haridwar UnionMandi & 2 & 1 & 2 & 5 & 0 & 5 & 3 & 5 & 5 \\
\hline & 10 & Total Garhwal Division & 4 & 3 & 3 & 9 & 1 & 10 & 7 & 9 & 9 \\
\hline B & & Kumoun Division & & & & & & & & & \\
\hline 1 & 5 & Rudra Pur Mandi & 2 & 2 & 0 & 3 & 2 & 5 & 3 & 4 & 4 \\
\hline \multirow[t]{3}{*}{2} & 5 & Haldwani Mandi & 3 & 0 & 2 & 2 & 3 & 5 & 2 & 5 & 4 \\
\hline & 10 & Total Kumoun Division & 5 & 2 & 2 & 5 & 5 & 10 & 5 & 9 & 8 \\
\hline & 20 & Total Uttarakhand & 9 & 5 & 5 & 14 & 6 & 10 & 12 & 18 & 17 \\
\hline
\end{tabular}

Source: Field Survey 
Graph-1 (a)

Mandi Wise Suggestions for Improvements Given by Sample Grocery Retailer

\begin{tabular}{|c|c|c|c|c|c|c|c|c|c|c|}
\hline \multicolumn{1}{|c|}{ Mandi Wise Suggestions given by Sample Grocery Retailing of Uttarakhand for improvement } \\
in Grocery Retailing
\end{tabular}

Graph-1 (b)

Mandi Wise Suggestions for Improvements Given by Sample Grocery Retailer

Mandi Wise Suggestions given by Sample Grocery Retailing of Uttarakhand for improvement in Grocery Retailing

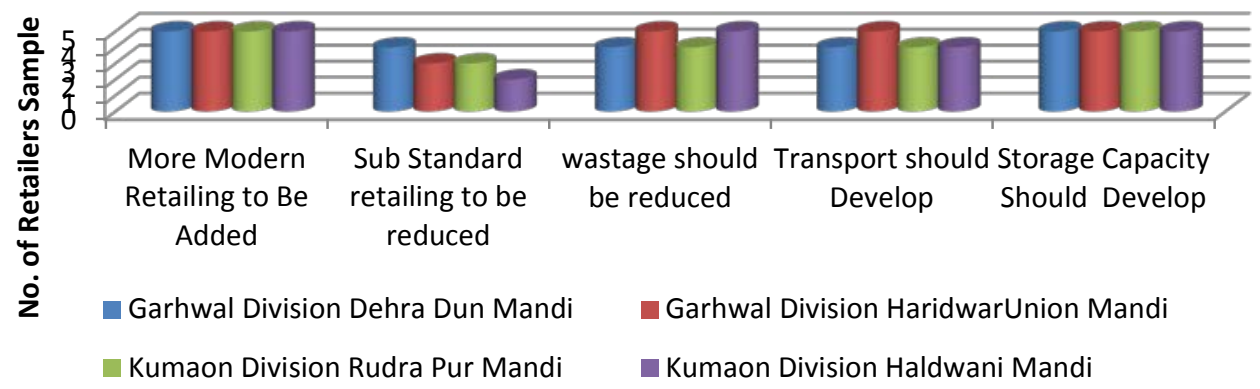


1) The maximum wastage was reported in case of fine cereals in Uttarakhand. Which was nearly $8.27 \%$ of whole of its selling in gunny bag, $3.13 \%$ of whole of its selling in plastic bag, and $7.75 \%$ of whole of its selling in other format of packing. So we observe nearly $19.15 \%$ of whole of its fine cereal selling is being wasted at the time of handling, at retailer point.

2) The maximum wastage was reported in case of coarse cereals in Uttarakhand. Which was nearly $2.37 \%$ of whole of its selling in gunny bag, $1.40 \%$ of whole of its selling in plastic bag, and $3.87 \%$ of whole of its selling in other format of packing. So we observe nearly $7.64 \%$ of whole of its coarse cereal selling is being wasted at the time of handling at retailer point.

3) The maximum wastage was reported in case of pulses in Uttarakhand. Which was nearly $2.53 \%$ of whole of its selling in gunny bag, $0.87 \%$ of whole of its selling in plastic bag, and $1.37 \%$ of whole of its selling in other format of packing. So we observe nearly $4.77 \%$ of whole of its pulses selling is being wasted at the time of handling at retailer point.

4) The maximum wastage was reported in case of other groceries in Uttarakhand. Which was nearly $2.50 \%$ of whole of its selling in gunny bag, $2.85 \%$ of whole of its selling in plastic bag, and $1.30 \%$ of whole of its selling in other format of packing. So we observe overall nearly $6.65 \%$ of whole of its other groceries selling is being wasted at the time of handling at retailer point.

We analyzed these data from grocery point of view, though various reasons of wastages of groceries were involve in this finding. So we observed that at retailer point wastages of grocery which was generally assumed quite low in whole of its chain, i.e. from Form House to End consumer had sufficient account of waste, in this hilly region having number of reasons for this wastages as loading, unloading, storage, carrying, weather, rat, weighing time. The causes of wastage of groceries were lack of storage, poor transportation, small creatures like rat etc. and bad weather in Uttarakhand, absence of warehouses, as expressed by majority retailers. Few retailers were of the views that inventory management and procurement at retailer's level was another major reason of the wastages of the grocery product. Mishandling of the grocery at loading and unloading and at customers' delivery time was also assumed to be a major reason. Though it had been majorly removed by adopting the improved format in packing of grocery.

For wastes they suggested modern formats of retailing along with developed transportation as well as storage facilities in whole of Uttarakhand and its main mandies of groceries. The suggestion given by retailers are of varying nature related to problem of mandies, about structural growth of mandi, about development of new packing formats, reduce the substandard quality of grocery was a major concern of retailers, they were of the same view that by reducing the wastages, we could easily reduce the substandard delivery of groceries, the tendency to consume the wastages was one of the major reason of sub standard delivery. 
For reducing the losses occurred by wastages which was heavy in percentage, retailers generally tried to sell them out after drying, polishing, mixing, or reducing the price. This was the major cause of sub standard delivery.

\section{FINDING AND SUGGESTIONS}

1. Regarding wastages in grocery retailing it was found that maximum wastages were reported in case of fine cereals in whole of Uttarakhand. Therefore modern formats must be adopted in whole of the Uttarakhand.

2. To reduce wastages and substandard groceries also, the retailers suggested adopting modern formats of retailing along with the developed transportation, storage and infrastructural facilities in Uttarakhand as a whole.

3. We would have to develop awareness among the retailers to adopt appropriate format for packing to reduce volume of wastages.

4. Volume of the wastages is quite high (nearly 15\%) in unorganized retailing in Uttarakhand in comparison to International figures (nearly 5\%) in retailing, so it is a need of time to develop infrastructure and awareness among the unorganized sector.

\section{Implication}

Wastages of groceries is very old issue and should be dealt seriously, on the one hand it increases the burden over retailers, increases the possibility of under quality product while on the other hand it increases the rate of groceries. By observing the retailers' suggestions and collected figures we can say that by adopting modern formats of packaging, fast and effective transportation, developing ware houses, reduce stocks, developing awareness among the retailers related to inventory maintenance wastages can be reduced and controlled.

\section{Future agenda}

Inventory management, supply chain, shop management adopted by unorganized retailers, to make investment effective and more profit oriented, effective and efficient storage of grocery to reduce wastages can be area of excavation.. Packaging of grocery may be another new area to explore from unorganized retailing point of view. Ready to eat grocery product could be another area of grocery retailing which may make impact over the future of grocery production, consumption as well as retailing.

\section{REFERENCES}

1) "The role of food retailer and technology in reducing food wastages" Carolina arios bustos, Capgemini, Carolina.ariosbustos@capgemini.com

2) Das (2016), “Competitive strategies of unorganized retailers" IOSR Journal of Business and Management (IOSR-JBM) eISSN: 2278-487X, $p$-ISSN: 2319-7668. PP 05-09 www.iosrjournals.org

3) Gustavsson et al (2011) Global food losses and food waste: Extent causes and Prevention" Food \& Agriculture Organization United Nations, Rome 2011

4) Li \& Yang (2014) "New business model for company to win the competition" American Journal of Industrial and Business Magazine, Vol4, 190-198.

5) Mahajan \&Vakharia," Waste management : A reverse supply chain perspective" VIKALAPA the jornal for decision makers, 41(3), 197-208

6) Oliver Wyman (2014) "Reducing food and waste how can retailers help" study by Oliver Wyman a global leader in management consulting

7) Prasad \& AryaSri (2011) "Effect of shopper attributes on retail format choice behaviour for food and grocery retailing in India", International Journal of Retail $\mathcal{E}$ Distribution Management, Vol 39(1), 68-86. 
8) Report (2011) "Global food losses and food waste" Study conducted for the International Congress at Germany by Food and agriculture organization of united nations

9) Report European Union (2014) "Counting the cost of food waste: Food wasteprevention" European Union committee 10th Report of Session 2013-14

10) Saini \& Grewal (2016) "Problem and prospect of retailing in Haryana" Radix International Journal of Research in Marketing ISSN 2250-3986, Vol 5,Issue 1.

11) Sinha and Kar (2007) "An insight in to the growth of new retail formats in india", Indian Institute of Management, Ahmadabad Working Paper No. 2007-03-04.

12) Sinha, Gokhale \& Thomas (2012) "Development of modern retailing in India- Its impacts on distribution and procurement networks and changing consumption pattern" Indian Institute of Management, Ahmadabad, Working Paper No. 2012/12/4.

13) Sivara et al (2005) "Reducing shrink to improve retailer profitability" Article by CISCO systems Inc. Internet business solution group(IBSG)

14) Thenmozhi \& Dhanpal (2011)" Unorganized retailing in India - A study on retail service quality" European Journal of Social Sciences Vol 23.

15) Torlok, Uzkurt \& Ozmen (2010) "Dimension of service quality in grocery retailing- A case from Turkey" Management Research Review, Vol 33, No 5, 413-422.

16) Weber et al (2012)"The Challenge of Food Waste- Retailers step up to the next level of inventory management" report of planetretail.net

17) Whitehead et al (2013) "Estimates of waste in the food and drink supply chain" www.wrap.org.uk

18) Young \& Russell "Sustainable retailing : Influencing consumer behavior of a food waste" University ofLleads, USA 